\title{
Developing Instructional Material on Problem-Based Learning of Food and Food Digestion System at SMAN 5 Palu
}

\author{
Musdalifah Nurdin \\ Tadulako University \\ Palu, Indonesia \\ ifahnurdin@untad.ac.id \\ Samsurizal M. Suleman \\ Tadulako University \\ Palu, Indonesia
}

\author{
Irawaty A. Pana \\ SMA Negeri 5 Palu \\ Palu, Indonesia \\ irawaty_andipana@yahho.co.id
}

\begin{abstract}
This research is a development research with limited testing that aims to develop learning tools and systems based on the digestion of food covered problem-based learning such as teaching materials, teacher's and student's guide, learning implementation plan, student worksheets, achievement test. Object of this study is students of XI IPA 5 SMAN 5 Palu with the number of students by 28 people. Development procedures used in this study is a definition Thiagarajan model; design stage, development stage, and deployment stage. Based conclusions of data analysis that have been obtained a product development device of food development and food digestion a valid and effective with problem-based learning model based on the second-grade students of SMA Negeri 5 Palu that consist of teaching materials, teacher guides, student guides, lesson plan, students worksheet and achievement test. It is known that the effectiveness of indicator results from limit from limited testing to demonstrate that the learning device that shows: (1) the average score that student obtained on test of learning outcomes is 86,00 meet the individuals who indicated exhaustiveness accomplished classically, (2) all categories of students who observed the activities meet all student's activities are ineffective category, (3) generally students give some positive response to the learning tools that used in learning teaching process, (4) the level of teacher capability in managing on process student's problem included in the categories very well with average of 3,70 , means that teacher performance can be maintained.
\end{abstract}

Keywords-Learning Tools, Food Digestion System, Problem-Based Learning, Teaching Materials, Learning Plan, Teacher Performance

\section{INTRODUCTION}

Problems in the world of formal education are more complex each year. The main problem in Indonesia is low quality of education in each level of education. The evidence of this problem is decreasing of Indonesia's education index ranking, from position 58 to position 62 of 130 countries based on the report of the United Nations Educational Scientific and Cultural Organization (UNESCO)[14].

Results of research in Southeast Asia on the provision of education in each country, Indonesia ranked thirteenth after Vietnam [14]. Therefore, the Indonesian nation must build themselves to be able to compete in many ways, especially improving the quality of Human Resources (HR) is closely related to the improvement of education through the activities outlined in the learning process.

Success in improving the quality of education at this time must not be separated from the educational process related to teaching and learning in the classroom. These activities require the interaction between teachers and students so that students can absorb the lesson material optimally. As educators who are directly involved in the learning process, teachers play an important role in directing students achieve maximum learning results. One of the expected ability is controlled by biology teachers how to teach the biological concept well, through the selection of models, methods and appropriate learning techniques.

Learning biology in the Curriculum 2013 is expected to process-oriented skills. That is the result of studying biology not only judged the product but more emphasis on the learning process. Thus, the student has expected an active role in the learning process.

Enforcement Curriculum 2013 requires a paradigm shift in education and learning, especially in the type and level of formal education. Such changes must also be followed by the professionalism of the teachers who are responsible for the implementation of school learning both in the classroom and outside the classroom.

SMAN 5 Palu is one of the high school that has implemented the curriculum of 2013. Implementation of the 
learning model in accordance with the curriculum of 2013 has not been fully implemented as expected. Based on observations that have been done in the school can be seen that the learning activities are still dominated by the teacher while the students only act as a listener and more passive.This causes most students difficulty studying biological materials and tend to think of biology as a subject of tedious memorizing. As a result of student learning outcomes decreases and causes a lot of students who did not complete. Facts show that only $63.33 \%$ of students in grade XI IPA at SMAN 5 Palu who completed. The rest, about $36.63 \%$ of students who have not completed the maximum absorption capacity reaches $62.72 \%$.

The condition is caused by many factors, especially the teaching materials and models are applied not in accordance with the demands of the curriculum. Thus the learning process cannot be optimized so that student learning outcomes is low.

Learning devices in SMA 5 Palu have been used, but not yet developed, and still needs to be pursued improvement, both in terms of content, as well as the determination of the learning model used has not been adjusted to the syntax so that less support in the learning process. To implement the teaching of biology, will need to establish a learning tool. The learning device arranged refers to the characteristics of problem-based learning model in the study of food materials and food digestive system. A fellow biology teacher at SMAN 5 Palu also confirmed that there are no teaching materials that accompanied with biology teacher guide and student guide.

Another fact that is found in the initial observations on the activity of the students at SMAN 5 Palu is underdeveloped of power in answering the students' critical thinking or tasks assigned by the teacher, either independent tasks or task groups. This author found on the activities of students in the classroom where the answer and tasks assigned by the teacher, students tend to copy the concept/text in textbooks without trying to grasp the concept that they copied through a given task. It has also become one of the causes of low student learning outcomes.

Learning model can be used, appropriate to the nature of the biological material, it can be used a problem-based learning model. This model is essential developed in middle school students for the implementation of problem-based learning model orient the students active learning (studentoriented) generate multi-directional interaction, social skills as well as a load of learning constructivism which is associated with the real-life students.

Under these conditions, need to be developed biological learning device that can help students and in expediting the process of learning and motivate student learning so that they can improve the quality of teaching biology.

\section{METHOD}

The type of this research is the research and development, namely the development of biology learning device that consisting of teaching materials, teacher guides, student guides, student activity sheet, lesson plan and achievement test.

Learning software development is using Thiagarajan models (model 4-D). The model is used specifically for the development of learning tools that explain in detail the operational steps software development.

Development of learning tools used is based on the model (4 - D) of Thiagarajan. The model consists of four stages as follows:

- Definition Phase, the activities carried out at this stage aims to define and determine the conditions of learning which includes learning objectives and learning materials restrictions.

- Design Phase, the activities carried out at this stage aims at designing a prototype of the learning device in the form of teaching materials, teacher guides, guide students, student activity sheet, learning implementation plan, and achievement test thus obtained Draft I which according to the study conducted.

- Development Phase, the activities carried out at this stage aims to produce learning tools and a good achievement test and has been revised based on input from experts and the data obtained from the tests.

- Deployment Phase, the activities carried out at this stage is the deployment of the learning device but this stage was not held because of limited funds and time of the study.

The research is conducted in SMA Negeri 5 Palu, through three stages: preparation, execution, and data analysis. Subjects were students of SMAN 5 Palu grade XI, 28 in total. Making the subject test was carried out with purposive sampling. Classes are used as research has the average value of homogeneous learning outcomes and student characteristics are known. The free trial class is treated using problem-based learning tools.

This type of data is qualitative data, the results of the assessment/response and comment of content expert, expert design/learning strategies, instructional media expert, individual testing, the small group trial and field trials. While quantitative data is data obtained from the data pretest and posttest results in field trials (data of student learning outcomes).

Data collection is performed by the learning device valuation techniques, test techniques, teacher and student activity observation technique. The instrument used in this study was a questionnaire, a test of learning outcomes, student activity observation sheet, observation ability sheets of teachers to manage the classroom.

Qualitative data analysis is about the effectiveness of problem-based learning using learning tools that have been developed. Analytical techniques such as analysis of instrument validity test, analysis of the validity of the learning device, learning device effectiveness data analysis. The effectiveness of study in question was how big the planned learning can be achieved. Achievement of the 
effectiveness of problem-based learning in the digestive system material, in this study, is based on four aspects: the thoroughness of student learning, the teacher's ability to manage learning, student activities, and the students' response to learning. Effective learning device and valid for material food and digestive system in this study is a learning device that has been through the stages of validation expert, stated that the device is categorized as good or excellent, and through trial, stages are categorized either.

\section{RESULTS AND DISCUSSION}

This study is based on the efforts to improve the quality of teaching biology that aims to produce valid and effective devices in particular food material and digestive system. In this research, problem-based learning applied to food materials and food in the digestive system SMAN 5 Palu class XI 5. This study is based on the efforts to improve the quality of teaching biology that aims to produce valid and effective devices in particular food material and digestive system. In this research, problem-based learning applied to food materials and food in the digestive system SMAN 5 Palu class XI 5.

\section{A. Development Learning Tool}

Based on the results of the development of the device, it is obtained by the learning device in the form of teaching materials, student guide, teacher guides, student activity sheet, learning implementation plan, and achievement test. In general, the validation results of the teaching material content expert subjects at the first validation, the percentage level of achievement of $77 \%$ are good qualifications. While in the second validation percentage achievement level of $88 \%$, are in excellent qualifications. In the second validation increases for suggestions and comments from the expert, content has been revised where suggestions that need to be improved from the first questionnaire was revised in the second questionnaire, such as text editors, especially on the instructions, the preface, the issue/problem, and others.

The results components of the expert validation of design/learning strategies on the teaching materials, the percentage rate of $82.21 \%$ in the attainment are good qualifications. They are assessed on all aspects are correct but it still needs to be improved. Aspects picture where clarity and very precise image display, however, overall comments and suggestions on these materials, for the improvement is the name of the author, the text colors in need of repairs and the use of cover paper needs to be adjusted.

The results of the expert validation of design/learning strategies to guide teachers, the percentage of the level of achievement of $80 \%$ are good qualifications. The components are assessed on all aspects are appropriate but needs to be improved. While the results of the design validation/learning strategies to guide students, the percentage of the level of achievement of $80 \%$ are good qualifications. All items on all aspects of the question are right but need to be improved in this respect. The overall comments and suggestions to guide the student is the author's name, colors need variety, and include the matter of the final chapter and an answer key.

The results of the validation of learning media experts on teaching materials, the percentage of the level of achievement of $77 \%$ are good qualifications. The components are assessed on all aspects are appropriate but needs to be improved. Where the cover of, size of letters the quality of, cover image conformity color letters quite appropriate. After the revised advice and commentary from media experts on the teaching materials teaching materials proficiency level are not eligible to use.

The results of the validation of teaching media experts to guide teachers, the percentage of the level of achievement of $86 \%$ are in the excellent qualifications. The components are assessed on all aspects are appropriate but needs to be improved. While the results of the validation of teaching media experts to guide students, the percentage rate of achievement $83 \%$ are in good qualifications. All items on all aspects of the question are good but need to be improved, item questions about the accuracy of the size of the letters in the student guide very precisely. Comments and suggestions on the whole to guide the student is already feasible to use.

The media leads to something take/pass the information (messages) between the source (messengers) and the recipient.

The learning process can work well if the students interact with all of the senses. Teacher strives to present the stimuli that can be processed by a variety of senses. The more sensing devices that are used to receive and process information, the more likely the information is understandable and can be maintained in the memory of students. Students are expected to be able to receive and absorb with ease and good in the material presented.

Student engagement in learning activities is very essential, in the opinion of [1], that the classification of experience according to the level of the most concrete to the most abstract, where participation, observation, and experience provide an enormous influence on the learning experience absorbed by the student. Delivery of a concept to students would be well if the concept requires that students are directly involved in it when compared with the concept that only involves the students to observe alone [2].

Based on the above, then the use of learning media is expected to provide more concrete learning experiences to students and can enhance the activity of students in the learning media as an example of the LCD. Content, design, and media strategies used in the preparation of teaching materials, teacher guides, and student guides are very necessary to be considered so that the product is valid and effective use in the learning process. This is consistent with the idea that the media, teaching materials and methods that can increase the activity of students in learning [3] [4].

\section{B. Learning Effectiveness}

Based on the analysis of data on the learning effectiveness in question can be seen from the following description: 


\section{1) Exhaustiveness Student Results}

Based on the analysis results can be explained that the completeness of classically student learning outcomes has been achieved. The data show that 26 students from 28 students in grade XI 5 has been thoroughly studied or (86.00) complete student learning outcomes. Thus completeness classically student learning outcomes showing mastery of the food and digestive system is good.

The results of the analysis and evaluation of the student's answer sheet test results in an increase of students' cognitive abilities of post-test results of each meeting. Based on the students' acquisition of cognitive value, then the group of students who received learning outcome from the first meeting to the next meeting is given gifts of stationery (pens, books, erasers, pencil, and ruler). Interest awarded the prize is to make students more motivated in learning activities. Award prizes for the group perform in accordance opinions of [5], that the system of prize or award which is based on the appearance of a discussion group learning can create reward structures among students in a group so that these groups provide mutual reinforcement of social response to efforts oriented friend task. Besides that, also based on Maslow's theory of motivation which says that giving praise and reward is better than punishment. The statement is consistent with the idea that the motivation in learning activities will improve the response of learners in the learning activities [6] [7] [8].

The results of the post-test analysis show an increase in the average value of both the post-test each meeting or at the end of the post-test. Classically, the average value of 86.00 indicates that the student has completed. However, in individually, there are two students who do not complete with the average value of 7.14. Students who have not completed is given remedial until they have completed. The increase in the average value of students at post-test occurs because the student in the learning process has been used to experiencing a repetitive activity, making it easy to perform these activities at the next meeting.

In addition to the above, the increase in the value of posttest is also due at the next meeting, students have had the readiness cognitive better by giving task individually and is distributed by a teacher in two days prior to the study carried out. Students have the opportunity longer to read and summarize the material lessons at home. The opinion is appropriate with the idea that the administrative tasks can increase the activity and thought processes of learners [9] [10] [11].

\section{2) Student Response}

Based on the results of the descriptive analysis, showed that the students' responses to problem-based learning are positive. Biology students' response to varied, from the feeling that the biology is fun. From 28 students, 25 students $(78.14 \%)$ are pleased with biology. They managed to understand the material presented and give them a challenge in thinking atmosphere. From the results of the questionnaire is also known that 3 students $(21.86 \%)$ state that biology is sometimes difficult. The reasoned is that the teachers who teach them give unclear the explanation of material and practical and also oriented to answer the questions in the textbooks without providing a full explanation beforehand, and when students ask for further clarification, the teacher does not provide feedback. Moreover, they argued that teachers rarely associate the biological problems in everyday life and not leave issues more challenging them, so they are less motivated to study biology. But with the learning based on problems, they are more like biology, because according to them the biology has a lot of problems for them to solve. It is seen from the positive response of students stated that they are pleased to learn biology by using problem-based learning.

The response of students to instructional materials and student guidance states that 24 of 28 students $(85.71 \%)$ are happy with the teaching materials in which there are practical activities and worksheets that are used. The reason is, by using student worksheets easier to work on the problems/issues presented relate to everyday life. In addition, teaching materials and guides students really help them use teaching materials, where they can learn on their own. The reason is, the use of the word/explanation of the material and images contained on a fairly simple teaching material and making it easier for them to understand the material presented. However, 4 of 28 students (14.29) argues that there are several languages are used in teaching materials is not very clear and the problems presented tend to be a bit complicated to understand. But overall, students interested in teaching materials and students guide to use the teaching material.

Students in class XI SMA Negeri 5 Palu (100\%) pleased with problem-based learning because they think this model provides a new atmosphere in their learning process and not monotonous. Moreover, they argued that the presentation of the material associated with the real world allows them to easily understand the material. In addition, they argued that presentation of material associated with the real world and ease for them to understand the matter. They can also carry out in LKS either in groups so as to make them quick understand with matter is presented. Besides, they can discuss with friends and share knowledge and work together to solve the problem in the teaching material. Students who feel happy to be passionate and enthusiastic about learning, otherwise students are unhappy will not excited to learn and will have trouble. Feeling attracted to something that is being studied will affect interest in learning. Thus it would appear on students attitude of attention, interest, confidence, and satisfaction with the implementation of PBL learning that have a positive impact in the process and student learning outcomes.

The findings are appropriate with the opinions of [5], that the positive response will support the study because it can cause a positive attitude. A positive attitude will create interest, to train independent nature and responsibility, improve the spirit of hard work, be respectful opinion, and create a sense of brotherhood among discussion groups studied. Further motivation is growing, on the contrary, a negative response will be able to inhibit learning, because it 
does not deliver a positive attitude and does not support the interest and motivation will be difficult to develop.

The results of this study are appropriate with the results of previous studies using the model PBL [1] which proved that PBL learning can improve problem-solving skills and can lead to a positive impact on students' skills in resolving problems/issues are given, and formulate answers and solve problems in learning.

\section{3) Teachers Ability in Managing Learning}

The result showed that the average value of teacher's ability to manage to learn for each learning activity is the initial activity of 3.70 , the core activity of 3.72 , the final activity by $3.70,3.80$ for class atmosphere, so the average ability teachers in managing of to learn in field trials by 3.70 is in the excellent category.

The success of teachers to manage problem-based learning because the steps in the learning are easy and well organized by themselves. In addition, the teachers' success in managing the problem-based learning is supported by the discussion between researcher and teachers who teach in class XI IPA 5 about learning steps in the lesson plan and how to guide students.

Teachers act as mentors and stimulate learners to think to solve the problem. As a facilitator, the teachers train the ability of learners to think metacognition. When learners face the challenges of the problem and asked to find solutions, they are in a situation of inequity among its thinking scheme with new information that it faces. At this time, learners need of assistance for finding a solution so that the gap can be eliminated. Reference [10] states, in this situation the students take risks that could be generating interest in learning. When learners are faced with problems, they are out of comfort zone and then venturing to enter into a new situation that is full of risks.

Learning of PBL, creativity, and activeness of student thinking unfolds as students given situation or information by the teacher. Students are trained to observe the information and to receive such information, then the students are challenged to present ideas. Concepts or principles of biological material that are owned in order to create a problem, then think alternative steps to resolve and then finish. The learning conditions will change the role of the teacher than just conveying information facilitators facilitate student learning. The changing role of the teacher as this is one of the characteristics that indicate success in learning with PBL models [10].

The learning condition is clearly visible during the implementation of learning. The application of PBL models can reduce the dominance of the teacher to explain the subject matter. This is consistent with the scenario of the lesson plan, in which the teacher's role is only at the beginning of the delivery of learning objectives learning and motivation by digging the prior knowledge of students through questions and organize discussion groups of students in learning. The next stage is in phase 2, 3, 4 which is the core learning activities, carried out by the students are reading the subject matter, resolve the concerns expressed in teaching materials.

Similar to the foregoing, the constructivist view assumes that our knowledge it is the construction (formation) of us who know something [11]. The essence of the constructivist theory is the idea that students have to personally find and transfer the information, the role of the teacher as a facilitator who helps students find the facts, concepts, and principles, instead of controlling all activities in the classroom [5].

Based on the above opinion, means that students will be able to discover and transform complex information into a more concrete situation. They also make the learning process through PBL learning model performed individually on learning groups based on an assessment of the subject matter material, especially food and digestive system. With the onset of activity, students examine the subject matter in depth prior to solve the problem and formulate the answer. Then, they build a meaningful understanding of the material and can also build and increase confidence in himself as well as educating a high sense of responsibility towards the tasks of learning [5].

Based on these results, it associates with previous research, it can be concluded that the learning materials of food and digestive system with based on the model PBL is done individually in study groups and allocate appropriate time and can shape the learning process in a more meaningful so that ultimately can improve process, learning outcomes and student response. PBL Learning Model is one of the innovative learning models that can provide active learning conditions for students [12]. PBL is an instructional model that involves students to solve a problem through the stages of the scientific method so that students can learn the knowledge related to these issues and also have the skills to solve problems [13].

\section{CONCLUSION}

Device learning biology in food and digestive system food material are valid and effective with learning model based on a problem in class XI IPA at SMAN 5 Palu. A device produced is teaching materials, teacher's guide, student's guide, lesson plans, worksheets, and achievement test.

\section{ACKNOWLEDGMENT}

Further thanks to the Head of SMAN 5 Palu, teachers, and education personnel with the permission and assistance provided during the study period.

\section{REFERENCES}

[1] Trianto. Mendesain Model Pembelajaran Inovatif-Progresif. Jakarta: Kencana Prenada Media Group.

[2] J. C. Maxwell, A Treatise on Electricity and Magnetism, 3rd ed., Vol. 2. Oxford: Clarendon, 1892, pp.68-73.2010.

[3] G.Bas, Investigating the Correlation Between Students' Perceptions on the Constructivist Learning Environment and their Academic Success in Science Course with Path Analysis. Journal of Baltic Science Education (online), Vol. 11, No. 4, pp. 367-379.2012.

[4] T.Amir, Inovasi Pendidikan Melalui Problem Based Learning. Jakarta: Kencana Prenada Media Group.2009. 
[5] Arends, R. Learning to Teach Belajar untuk Mengajar. Yokyakarta: Pustaka Pelajar.2008.

[6] Slavin, R. E. Cooperative Learning: Theory, Research, and Practice. Boston: Second Edition. Allyn and Bacon Publisher.1995.

[7] Gaeta, L. M; Teruel, P. M; \& Orejudo, S. Motivational, Volitional and Metacognitive Aspects of Self-Regulated Learning. Electronic Journal of Research Psychology, Vol. 10, No. 1, pp. 073-094.2012.

[8] Sevinc, B; Ozmen, H; \& Yigit, N. Investigation of Primary Students' Motivation Levels Toward Science Learning. Science Education International: Vol.22, No. 3, pp. 218-232.2011.

[9] Tuan, H.L., Chin, C. C., and Shieh, S. H. The Development of a Questionnaire to Measure Students' Motivation Towards Science Learning. International Journal of Science Education. Vol. 27, No. 6, pp. 639-654.

[10] Darwis, M. Model Pembelajaran Berbasis Masalah Pada Pokok Bahasan Statistika. Tesis tidak diterbitkan. Malang: Program Pascasarjana Universitas Negeri Malang.2007.

[11] Arend, R.I. Learning to Teach. Nine edition. Mc Graw Hill. Connect Learn Succeed.2012.

[12] Bay, E. Development of "Leaner Roles in Constructive Learning Environment" Scale. Electronic Journal of Research in Educational Psychology (online), Vol. 9, No. 2, pp. 893-910.2011.

[13] Savery, J.R. and Duffy T.M. Problem-Based Learning: An Instructional Model and Its Constructivist Framework. Educational Technology, Vol. 35, pp. 31-38. Indiana University.1995.

[14] Merrill, D. M. Constructivism, and instructional design. Educational Technology, Vol. 31, No. 5, pp. 45-53.1991.

[15] The United Nations Development Programme. Human Development Report 2016: Indonesia. 2016. 